\title{
PENGEMBANGAN MODEL PEMBELAJARAN GERAK MULTILATERAL BERBASIS ROLE PLAYING GAME (RPG) PADA SISWA SEKOLAH DASAR
}

\author{
Dedy Putranto ${ }^{1}$, Widati Amalin Ulfah $^{2}$ \\ STKIP Muhammadiyah Bangka Belitung ${ }^{1}$ \\ STKIP Muhammadiyah Bangka Belitung ${ }^{2}$
}

dedy.putranto@stkipmbb.ac.id

\begin{abstract}
ABSTRAK
Latar belakang dalam penelitian ini yaitu berkembangnya bentuk model pembelajaran pendidikan jasmani dari waktu ke waktu hingga saat ini terus mengalami perubahan. Dengan terjadinya bentuk perubahan tersebut maka guru pendidikan jasmani dituntut agar dapat menggunakan model pembelajaran yang tepat. Penelitian ini bertujuan untuk memberikan variasi gerak multilateral berbasis role playing game yang dilakukan oleh siswa sekolah dasar kelas bawah. Penelitian ini termasuk jenis penelitian dan pengembangan (research and development) yang mengacu pada model penelitian dan pengembangan Borg and Gall: (1) melakukan analisis kebutuhan; (2) pembuatan produk awal; (3) tinjauan para ahli yang meliputi dua ahli pembelajaran dan satu ahli pendidikan jasmani; (4) ujicoba kelompok kecil; (5) revisi produk awal; (6) ujicoba kelompok besar; (7) revisi produk akhir. Subjek dalam penelitian ini adalah siswa sekolah dasar kelas bawah. Hasil akhir penelitian ini berupa model gerak multilateral berbasis role playing game yang telah dievaluasi oleh para ahli, tahap uji coba dan revisi. Dari hasil uji validasi ahli diperoleh nilai rata-rata sebesar $93,1 \%$ dalam kriteria sangat layak atau sangat baik, dari hasil ujicoba kelompok kecil diperoleh nilai rata-rata sebesar 87,5\% dalam kriteria sangat layak atau sangat baik dan hasil ujicoba kelompok besar diperoleh nilai rata-rata sebesar $88,8 \%$ dalam kriteria sangat layak atau sangat baik. Dengan demikian dapat disimpulkan bahwa model pembelajaran gerak multilateral berbasis role playing game sangat baik untuk diterapkan pada siswa sekolah dasar kelas bawah.
\end{abstract}

Kata Kunci : Model Pembelajaran, Gerak Multilateral, Role Playing Game

\begin{abstract}
The background of this research is due to the limited knowledge of sports teachers of a learning model used that decreases students' enthusiasm in learning. The research aims to give a varied multilateral move of a roleplaying game - based done by the lower classes of elementary school students. This study is a research and development research by Borg and Gall: 1) needs analysis; 2) preliminary product; 3) expert judgments that included two learning specialists and one physical education specialist; 4) small group test; 5) preliminary revision; 6) large group test; 7) final revision. The subject of the research is the lower classes of elementary school students. The research result is the model of the multilateral move of a role-playing game - based which had been revised by the experts, tests and revision. The validation result shows that the median score is $93.1 \%$ in very good criterion, the median of the small test result is $87.5 \%$ in very good criterion, and the median of the large test result is $88.8 \%$ in very good criterion. It concludes that the learning model of a role-playing gamebased is efficient to teach to elementary school students of lower classes.
\end{abstract}

Keywords; learning model, multilateral move, role playing game

Dipublikasikan Oleh :

UPT Publikasi dan Pengelolaan Jurnal

Universitas Islam Kalimantan Muhammad Arsyad Al-Banjari Banjarmasin 


\section{PENDAHULUAN}

Dalam pembelajaran pendidikan jasmani siswa dituntut untuk aktif dalam segala sesuatunya. Karena pendidikan jasmani tidak hanya dipahami secara teori namun juga secara praktik termasuk pada materi gerak dasar pada siswa sekolah dasar. Salah satu kompetensi yang harus dimiliki oleh siswa sekolah dasar yaitu mempraktikkan gerak dasar jalan, lari dan lompat dalam permainan sederhana serta nilai sportivitas, kejujuran, kerjasama, toleransi dan percaya diri. Oleh karena itu mengembangkan pola gerak dasar merupakan salah satu tujuan pembelajaran pendidikan jasmani yang harus dicapai oleh seluruh siswa dalam menyelesaikan jenjang pendidikannya. Permasalahan yang masih sering terjadi dalam pelaksanaan proses pembelajaran pendidikan jasmani salah satunya di SD Muhammadiyah Pangkalpinang khususnya siswa kelas rendah yaitu guru masih menggunakan pendekatan secara konvensional. Pendekatan ini belum memberikan hasil belajar secara maksimal karena kurang memperhatikan kebutuhan bagi setiap siswa. Hal itu tentunya tidak sejalan dengan tujuan pendidikan jasmani yang lebih mengarah kepada pengembangan kualitas gerak siswa. Berkaitan dengan hal tersebut maka diperlukan upaya guru pendidikan jasmani untuk mengembangkan model pembelajaran gerak dasar sesuai dengan tingkat pertumbuhan dan perkembangan siswa.

Pendidikan jasmani merupakan proses pendidikan yang memanfaatkan aktivitas jasmani yang telah direncanakan secara sistematik dengan tujuan untuk mengembangkan dan meningkatkan individu secara organik, kognitif, dan emosional dalam kerangka sistem pendidikan nasional. Oleh karena itu melalui pendidikan jasmani yang diarahkan dengan baik, anak dapat mengembangkan keterampilan yang berguna bagi dirinya, terlibat dalam aktivitas yang terjaga untuk mengembangkan pola hidup sehat, berkembang secara sosial, dan menyumbang pada kesehatan fisik. Pendidikan jasmani merupakan bagian yang tidak dapat dipisahkan dari kehidupan manusia, melalui pendidikan jasmani manusia dapat belajar lebih banyak hal yang berhubungan dengan afektif, kongnitif, dan psikomotor yang merupakan bekal manusia untuk mencapai tujuan hidup (Hanief \& Sugito, 2015)

Menurut Husdarta (2011) pendidikan jasmani adalah proses pendidikan yang memanfaatkan aktivitas fisik dan untuk menghasilkan perubahan holistik dalam kualitas individu baik dalam hal fisik, mental serta emosional. Pendidikan jasmani olahraga dan kesehatan merupakan salah satu mata pelajaran yang dilaksanakan pada jenjang pendidikan dasar, menengah, bahkan pada pendidikan tinggi.

Badan Standar Nasional Pendidikan (BSNP)) juga mengemukakan bahwa Pendidikan jasmani, olahraga dan kesehatan bertujuan agar peserta didik memiliki beberapa kemampuan diantaranya meningkatkan kemampuan dan keterampilan gerak dasar. Untuk mencapai semua tujuan pendidikan jasmani tersebut perlu dilakukan berbagai macam upaya yang harus dimulai dari usia dini salah satunya dengan mempelajari gerak dasar. Gerak dasar menjadi hal yang utama karena mendasari dari semua rangkaian gerak. Pengembangan motorik siswa sekolah dasar kelas bawah pada umumnya fokus pada penguasaan keterampilan gerak fundamental (Goodway, Ozmun, \& Gallahue, 2019, p.50).

Menurut Pangrazi (2007) gerak dasar (fundamental skill) adalah keterampilan yang membentuk dasar dari gerakan manusia. Gerak dasar terbagi menjadi 3 yaitu gerak lokomotor, non lokomotor dan manipultif. Gerak lokomotor merupakan gerak berpindah tempat. Gerak ini ditandai dengan pergerakan seluruh tubuh, dalam perpindahan tempat atau titik berat badan dari satu bidang tumpu ke bidang tumpu lainnya. Beberapa contoh yang termasuk dalam gerak lokomotor yaitu: berjalan, berlari, meloncat, dan jenis gerakan lainnya yang ditandai dengan perpindahan tempat. Gerak non lokomotor merupakan suatu gerakan yang dilakukan dalam satu tempat dan tidak ada pergerakan dari satu titik ke titik yang lainnya. Contoh gerak non lokomotor yaitu: membungkuk, mengayun, memutar, meregang dan jenis gerak lainnya yang tidak merubah posisi tubuh pada saat melakukan gerakan. Gerak manipulatif merupakan gerak yang membutuhkan koordinasi karena melibatkan beberapa unsur gerak. Contoh gerak manipulatif yaitu: menendang, melempar, menangkap, menyerang. Keterampilan gerak dasar merupakan bangunan dasar untuk aktivitas fisik dan olahraga ke depannya seperti halnya abjad ABC dalam pengenalan huruf (Goodway dkk., 2006; Gallahue dkk., 2012).

Perkembangan gerak dasar merupakan hal penting yang dilakukan pada anak usia sekolah dasar karena bersifat multilateral. Menurut Lumintuarso (2013) gerak multilateral merupakan penggabungan dari berbagai gerak dasar dan dasar gerak keterampilan olahraga. Keterampilan gerak dasar yang baik dan benar sesuai dengan pertumbuhan dan perkembangan bisa memberikan dampak yang positif bagi anak. Oleh karena itu dengan penyediaan pengalaman gerak yang beragam anak akan memiliki pola dan kesadaran gerak yang lebih kuat untuk mampu bergerak lebih efisien dalam berbagai situasi yang bervariasi (Lumintuarso, 2013). Pengembangan 
keterampilan gerak dasar yang dilaksanakan dengan baik, dapat membantu perkembangan anak terlebih dalam perkembangan motorik sehingga akan berpengaruh terhadap pengembangan keterampilan motorik anak pada saat melaksanakan kegiatan olahraga prestasi. Anak dapat lebih mudah melaksanakan aktivitas bermain ketika mempunyai landasan gerak dasar yang baik.

Dalam pembelajaran pendidikan jasmani siswa dituntut aktif karena pendidikan jasmani tidak hanya memahami secara teori saja melainkan juga dengan praktik. Berdasarkan observasi awal di kelas bawah siswa sekolah dasar yang dilakukan oleh peneliti di lapangan pada standar kompetensi mempraktikkan berbagai gerak dasar dalam permainan sederhana dan nilai-nilai yang terkandung didalamnya ditemukan bahwa proses kegiatan belajar mengajar pendidikan jasmani, guru belum menerapkan model pembelajaran. Siswa melakukan gerak dasar sesuai dengan kemauannya sendiri. Siswa juga sangat terbatas sekali dalam melakukan gerakan karena hanya menunggu instruksi dari guru, padahal pembelajaran yang harus dilakukan saat ini siswa harus lebih aktif. Disisi lain metode yang digunakan guru dalam mengajar juga kurang menarik, sehingga malah membuat siswa tidak tertarik untuk mengikuti pembelajaran. Hal tersebut tentunya menjadi kendala untuk mencapai tujuan pembelajaran jasmani yang sesungguhnya. Guru dituntut aktif dan kreatif dalam merancang bentuk-bentuk permainan untuk mengembangkan semua unsur kete-rampilan gerak dasar, sehingga siswa tergugah dan timbul motivasinya untuk mengembangkan keteram-pilan mereka. Oleh sebab itu, dengan kurang berhasil-nya strategi pembelajaran rangkaian permainan dalam mengembangkan keterampilan dasar bagi siswa, maka faktor guru sangat menentukan untuk keberhasilan penerapan strategi pembelajaran rangkaian permainan di masa yang akan datang (Syahrial, 2014).

Dengan proses pembelajaran pendidikan jasmani yang baik dapat mencerminkan kualitas mutu dalam pembelajaran tersebut. Salah satu upaya yang bisa dilakukan guru untuk mencapai suatu proses pembelajaran yang baik yaitu dengan menerapkannya model serta metode yang tepat. Menurut Hopkins (2008) bahwa model pembelajaran adalah kealamiahan isi pembelajaran, strategi belajar dan susunan interaksi sosial yang dapat menciptakan suasana belajar bagi siswa. Hal yang sama juga dikemukakan Rahyubi (2012) bahwa model pembelajaran adalah kerangka konseptual yang melukiskan prosedur sistematis dalam mengorganisasikan pengalaman belajar untuk mencapai dari tujuan pembelajaran tersebut. Berdasarkan pernyataan diatas dapat disimpulkan bahwa model pembelajaran adalah cara interaksi antara guru dengan siswa didalam proses pembelajaran yang menyangkut metode, strategi, pengelolaan kelas serta pendekatan yang dirancang untuk menciptakan suasana belajar yang efektif dan efisien. Melihat permasalahan yang ada maka peneliti ingin mengembangkan gerak multilateral berbasis role playing game.

Pada dasarnya role playing game atau bermain peran adalah cara penguasaan bahan-bahan pelajaran melalui pengembangan imajinasi dan penghayatan siswa. Permainan yang dilakukan dengan menggunakan metode ini pada umumnya lebih dari satu orang. Siswa dilibatkan secara aktif dalam proses pembelajaran. Siswa akan memerankan atau mempraktikkan sesuai dengan situasi yang berkaitan dengan materi yang disampaikan oleh guru. Berdasarkan hasil penelitian dengan judul pengembangan game edukasi kimia berbasis role playing game pada materi struktur atom sebagai media pembelajaran mandiri untuk siswa kelas X SMA di kabupaten Purworejo tahun 2014 yang dilakukan oleh Kurnia Wening Sari dapat disimpulkan bahwa game edukasi kimi berbasis role playing game yang dikembangkan memenuhi kriteria baik sebagai pembelajaran kimia mandiri. Ahli materi memberikan skor baik $(80 \%)$, ahli media memberikan skor baik $(82,40 \%)$, guru memberikan skor sangat baik $(84,09 \%)$, siswa pada uji lapangan awal memberikan skor baik $(82,44 \%)$, pada uji coba lapangan siswa memberikan skor baik $(82,67 \%)$ dan pada uji pelaksanaan lapangan siswa memberian skor sangat baik $(84,97 \%)$. Hasil penelitian Bakhtiar (1999) menunjukkan bahwa kemampuan gerak dasar siswa SD Kecamatan Padang Utara Kota Padang banyak yang belum matang sesuai degan tingkat pertumbuhan dan perkem-bangannya. Untuk berlari, 52\% siswa masih tergolong tingkat dasar; melompat, 59,46\% siswa masih tergo-long pemula; keseimbangan, 60,36\% siswa masih tingkat dasar; dan lempar, 51,66\% siswa serta me-nangkap, 60,66\% siswa masih tergolong pemula. Dengan demikian dapat dikatakan banyak siswa yang belum baik perkembangan keterampilan geraknya.

Metode pembelajaran permainan menuntut anak untuk ikut aktif dalam menjalankannya, dan pendidik cenderung hanya sebagai pengarah dan fasilitator. Siswa berperan utama dalam menjalankan kegiatan pembelajaran. Siswa dituntut untuk mencari strategi bagaimana memenangkan permainan tersebut. Selain itu, siswa didorong untuk melakukan suatu pekerjaan yang mengarah pada tujuan yang hendak dicapai dan melatih tanggung jawab (Suparno, 2013). Metode bermain peran ini dipilih oleh peneliti karena selama proses pembelajaran siswa menjadi pusat perhatian. Siswa terlibat langsung dalam peran yang akan dimainkannya dan mengembangkan kemampuannya dalam memecahkan masalah yang dihadapi. Keterlibatan siswa secara langsung inilah diharapkan agar siswa lebih aktif dalam pembelajaran sehingga mampu mencapai hasil belajar siswa yang maksimal. 


\section{METODE}

Jenis penelitian ini merupakan penelitian pengembangan (Research and Development) yang mengacu pada model pengembangan Borg and Gall. Produk dari penelitian dan pengembangan berupa model pembelajaran gerak multilateral berbasis role playing game yang dilengkapi dengan buku panduan gerak multilateral berbasis role playing game. Langkah-langkah yang digunakan dalam penelitian ini merujuk pada Borg and Gall (1983: 774-775) yaitu sebagai berikut :

(1) Research and information collecting-Includes review of literature, classroom observation and preparation of report of state of the art. (2) Planning-Includes defining skill, stating objectivedetermining course sequence and small scale feasibility testing. (3) Develop preliminary form of product-Includes preparation of instructional materials, handbooks and evaluation device. (4) Preliminary field testing-Conducted in form 1 to 3 schools, using 6 to 12 subjects. Interview, observational and questionnaire data collected and analyzed. (5) Main product revision-Revision of product as suggested by the preliminary field-test result. (6) Main field testing-Conducted 5 to 15 school with 30 to 100 subjects. Quantitative data on subjects precourse and postcourse performance are compared with control group data, when appropriate. (7) Operational product revision-revision of product as suggested by main field-test result. (8) Operational field testing-Conducted in 10 to 30 school involving 40 to 200 subjects. Interview, observational and questionnaire data collected and analyzed. (9) Final product revision-Revision of product as suggested by operational field-test result. (10) Dissemination and implementation Report on product at profesional meeting and journals. Work with publisher who assumes commercial distribution. Monitor distribution to provide quality control.

Dalam penelitian ini peneliti menggunakan 7 langkah yang sederhana dengan mengacu pada langkahlangkah penelitian yang ada pada diatas. Ada 7 dari 10 langkah yang digunakan oleh peneliti dalam pengembangan model pembelajaran gerak multilateral berbasis role playing game. Jadi berdasarkan kebutuhan penelitian dan pengembangan yang berjudul pengembangan model pembelajaran gerak multilateral berbasis role playing game pada siswa sekolah dasar, maka rancangan pengembangan produk dapat digambarkan seperti dibawah ini:

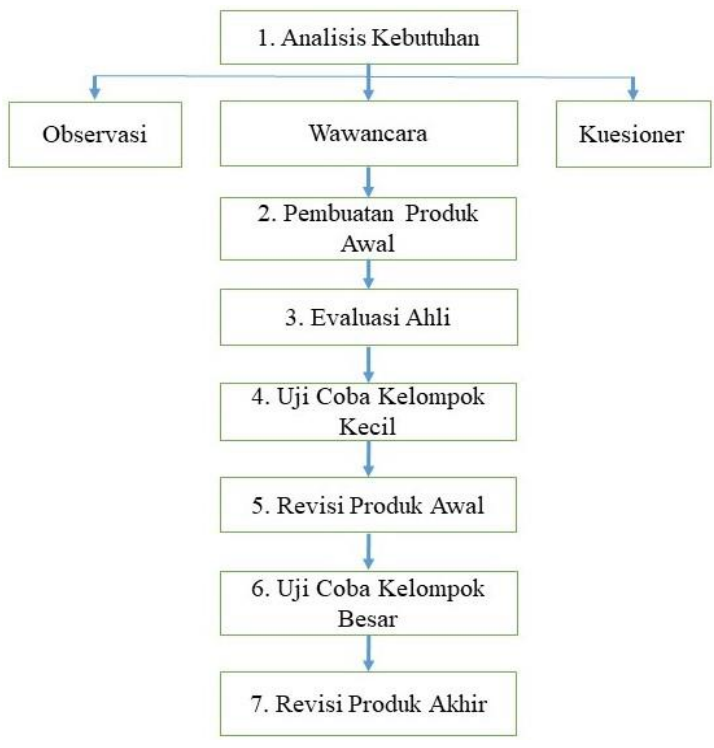

Gambar 1. Model Prosedur Pengembangan dari Borg and Gall

Penelitian dan pengembangan ini hanya menggunakan 7 dari 10 langkah yang telah dikemukakan oleh Borg and Gall dikarenakan langkah-langkah yang diambil disesuaikan dengan kebutuhan penelitian dan pengembangan yang akan dilakukan. Prosedur penelitian dan pengembangan yang digunakan dalam penelitian ini yaitu sebagai berikut:

1. Penelitian dan pengumpulan data dalam analisis kebutuhan dilakukan dengan cara wawancara pada 1 orang guru pendidikan jasmani dan memberikan angket pada 10 orang siswa sekolah dasar kelas bawah.

2. Melakukan perencanaan penelitian.

3. Mengembangkan rancangan produk pengembangan model pembelajaran gerak multilateral berbasis role playing game. Produk yang sudah dibuat oleh peneliti kemudian dilakukan evaluasi kepada 3 orang ahli yaitu 2 ahli pembelajaran dan 1 ahli pendidikan jasmani. 
4. Uji coba kelompok kecil dilaksanakan di SD Muhammadiyah Pangkalpinang dengan jumlah subjek 15 siswa.

5. Melaksanakan revisi produk sesuai dengan hasil uji coba kelompok kecil.

6. Uji coba kelompok besar dilaksanakan di SD Muhammadiyah Pangkalpinang dengan jumlah subjek 40 siswa.

7. Menyempurnakan dan merevisi produk sesuai dengan saran dan masukan dari hasil uji coba kelompok besar.

Adapun rincian pelaksanaan penelitian sebagai berikut: 1). Studi pendahuluan dilaksanakan pada tanggal 25 November 2019 dengan melakukan wawancara terhadap guru pendidikan jasmani dan memberikan kuesioner kepada 10 siswa. 2) Peneliti merancang model pengembangan gerak multilateral berbasis role playing game. 3) Rancangan model yang sudah dibuat kemudian divalidasikan kepada 3 ahli apakah model yang dibuat sudah sesuai atau belum. 4) Setelah mendapat hasil validasi dari 3 ahli, maka peneliti memperbaiki model sesuai dengan saran atau pun catatan dari masing-masing validator. Setelah diperbaiki maka model tersebut diujikan pada kelompok kecil, dimana uji kelompok kecil ini dilakukan dengan jumlah subyek 15 siswa pada tanggal 11 Februari 2020. 5) Dalam uji lapangan skala kecil ini peneliti masih perlu memperbaiki model yang telah dibuat dan diujicobakan berdasarkan dari hasil penilaian siswa dan evaluasi para ahli. 6) Setelah model diperbaiki maka akan diujicoba kembali ke lapangan dengan skala yang lebih besar yaitu dengan subjek penelitian 35 siswa pada tanggal 27 Februari 2020. Pada tahap ini merupakan tahap uji coba terakhir. Maka apabila masih ada perbaikan peneliti segera memperbaiki sehingga dapat menyempurnakan produk akhir

Uji coba produk dilakukan untuk mengumpulkan data yang digunakan untuk menilai kelayakan produk yang akan dikembangkan. Dalam hal ini yang harus diperhatikan adalah desain uji coba, subjek uji coba, instrumen pengumpulan data dan teknik analisa data. Desain uji coba ini dilakukan dalam 3 tahapan yaitu evaluasi ahli, uji coba kelompok kecil dan uji coba kelompok besar. Pada tahap evaluasi ahli ini peneliti sudah membuat rancangan pengembangan model dan kemudian dievaluasi oleh para ahli dengan instrumen angket. Hasil evaluasi dari ketiga ahli digunakan sebagai acuan untuk menyempurnakan produk gerak multilateral berbasis role playing game. Pada tahap uji coba kelompok kecil ini dilaksanakan di SD Muhammadiyah Pangkalpinang dengan dengan subjek 15 siswa. Hasil dari uji coba ini kemudian dianalisa dan selanjutnya dijadikan acuan untuk uji coba kelompok besar. Uji coba kelompok besar dilaksanakan di SD Muhammadiyah Pangkalpinang dengan jumlah subjek 35 siswa. Hasil dari uji coba kelompok besar kemudian dianalisa dan selanjutnya dijadikan acuan untuk merevisi produk akhir dari pengembangan gerak multilateral berbasis role playing game.

Jenis data yang digunakan berupa data kualitatif dan kuantitatif. Data kualitatif diperoleh dari masukan para ahli yang berupa saran dan evaluasi. Sedangkan data kuntitatif diperoleh dari penelitian awal terhadap siswa dan guru pendidikan jasmani untuk mengetahui kebutuhan produk yang akan dikembangkan serta dara dari hasil uji coba kelompok kecil dan kelompok besar. Instrumen yang digunakan berupa angket. Teknik analisa data yang digunakan yaitu teknik analisis deskriptif kualitatif berupa prosentase. Teknik ini digunakan untuk menganalisis dari data analisis kebutuhan awal, uji coba kelompok kecil dan uji coba kelompok besar.

Tabel 1. Interpretasi Nilai

\begin{tabular}{|c|c|}
\hline Rentang Skor $(\mathbf{x})$ & Kualifikasi \\
\hline $82 \%<\mathrm{x} \leq 100 \%$ & Sangat Layak/Sangat Baik \\
\hline $63 \%<\mathrm{x} \leq 81 \%$ & Layak/Baik \\
\hline $44 \%<\mathrm{x} \leq 62 \%$ & Kurang Layak/Kurang \\
\hline $25 \%<\mathrm{x} \leq 43 \%$ & Tidak Layak/Sangat Kurang \\
\hline
\end{tabular}

\section{HASIL DAN PEMBAHASAN}

Sumber : Sudjana (2005)

Berdasarkan dari hasil analisis kebutuhan yang dilakukan menggunakan kuesioner dapat diketahui bahwa: (a) 63,3\% siswa tidak mengetahui tentang bentuk pembelajaran gerak dasar, (b) 70\% siswa mengalami kesulitan dalam mengikuti pembelajaran pendidikan jasmani khusunya materi gerak dasar, (c) 56,7\% siswa merasa bosan ketika mempelajari gerak dasar, (d) 73,3\% siswa menyatakan bahwa kurang menyukai gerak dasar, (e) $86,7 \%$ siswa menyatakan bahwa perlu memasukkan unsur permainan dalam mempraktikkan gerak dasar, (f) 83,3\% siswa akan lebih termotivasi mengikuti kegiatan pembelajaran ketika guru mampu menerapkan model pembelajaran yang tepat. Adapun proses analisis kebutuhan awal juga dilakukan wawancara terhadap guru pendidikan jasmani dengan hasil sebagai berikut: (1) Guru belum memberikan metode pembelajaran melalui permainan dan belum pernah mempraktikkan variasi permainan dalam pembelajaran gerak dasar, sehingga minat siswa mengikuti pembelajaran bawah (2) Pemahaman siswa tentang pembelajaran gerak dasar minim dikarenakan metode penyampaian guru kurang bervariasi. (3) Guru setuju dikembangkannya model pembelajaran gerak dasar sehingga siswa lebih tertarik mengikuti pembelajaran dan siswa mudah memahami 
materi yang disampaikan oleh guru. Berdasarkan dari hasil analisis kebutuhan awal maka dapat disimpulkan bahwa perlunya pengembangan model gerak multilaeral berbasis role playing game.

\section{Validasi Draf Produk}

Produk awal model gerak multilateral berbasis role playing game sebelum dilakukan uji coba kelompok kecil maka perlu divalidasi terlebih dahulu oleh ahli. Proses validasi dilakukan dengan cara memberikan draf produk awal model gerak multilateral berbasis role playing game yang disertai dengan lembar evaluasi untuk 2 ahli pembelajaran dan 1 ahli pendidikan jasmani. Lembar evaluasi yang diberikan berupa kuesioner yang berisi aspek kejelasan, kesesuaian, kemudahan, keamanan, kualitas gerakan serta saran dan komentar. Berdasarkan hasil pengisian kuesioner yang dilakukan oleh ahli maka dapat dilihat pada tabel di bawah:

Tabel 2. Rekapitulasi Hasil Penilaian Validasi Ahli

\begin{tabular}{ccccc}
\hline No & Ahli & Skor diperoleh & Skor Maks & Persentase \\
\hline 1 & Ahli 1 & 22 & 24 & $91,7 \%$ \\
\hline 2 & Ahli 2 & 22 & 24 & $91,7 \%$ \\
\hline 3 & Ahli 3 & 23 & 24 & $95,8 \%$ \\
\hline & Rata-rata & & $93,1 \%$ \\
\hline
\end{tabular}

Berdasarkan tabel diatas diperoleh hasil pengisian lembar evaluasi yang dilakukan oleh 3 ahli dapat disimpulkan bahwa pengembangan model pembelajaran gerak multilateral berbasis role playing game mendapatkan nilai rata-rata sebesar $93,1 \%$ sehingga secara keseluruhan model yang dikembangkan dalam kategori sangat layak.

\section{Uji Coba Kelompok Kecil}

Pada tahap uji coba kelompok kecil ini dilaksanakan oleh siswa dengan jumlah subjek 10 orang. Adapun hasil dari uji coba kelompok kecil dapat dilihat pada tabel berikut:

Tabel 3. Rekapitulasi Hasil Ujicoba Kelompok Kecil

\begin{tabular}{ccccc}
\hline No & Aspek yang Dinilai & Skor diperoleh & Skor Maks & Persentase \\
\hline 1 & Kognitif & 32 & 40 & $80 \%$ \\
\hline 2 & Afektif & 36 & 40 & $90 \%$ \\
\hline 3 & Psikomotorik & 37 & 40 & $92,5 \%$ \\
\hline & & Rata-rata & & $87,5 \%$
\end{tabular}

Berdasarkan tabel di atas bahwa untuk hasil ujicoba kelompok kecil dari aspek kognitif diperoleh sebesar $80 \%$, hasil dari aspek afektif diperoleh sebesar $90 \%$ dan hasil dari aspek psikomotorik diperoleh sebesar $92,5 \%$, sehingga nilai rata-rata yang diperoleh dari ketiga aspek tersebut sebesar $87,5 \%$. Maka berdasarkan nilai rata-rata dari ketiga aspek tersebut dapat dinyatakan bahwa produk yang dikembangkan dalam kategori sangat layak.

\section{Uji Coba Kelompok Besar}

Pada tahap ujicoba kelompok besar dilaksanakan dengan jumlah subjek 35 siswa. Adapun hasil rekapitulasi ujicoba kelompok besar dapat dilihat pada tabel berikut:

Tabel 4. Rekapitulasi Hasil Ujicoba Kelompok Besar

\begin{tabular}{ccccc}
\hline No & Aspek yang Dinilai & Skor diperoleh & Skor Maks & Persentase \\
\hline 1 & Kognitif & 122 & 140 & $87,1 \%$ \\
\hline 2 & Afektif & 124 & 140 & $88,6 \%$ \\
\hline 3 & Psikomotorik & 127 & 140 & $90,7 \%$ \\
\hline & Rata-rata & & $88,8 \%$ \\
\hline
\end{tabular}

Berdasarkan tabel di atas bahwa untuk hasil ujicoba kelompok besar dari aspek kognitif diperoleh sebesar $87,1 \%$, hasil dari aspek afektif diperoleh sebesar 88,6\% dan hasil dari aspek psikomotorik diperoleh sebesar $90,7 \%$, sehingga nilai rata-rata yang diperoleh dari ketiga aspek tersebut sebesar 88,8\%. Maka berdasarkan nilai rata-rata dari ketiga aspek tersebut dapat dinyatakan bahwa produk yang dikembangkan dalam kategori sangat layak. 
Model Akhir

Gambar dibawah merupakan bentuk model akhir pengembangan gerak multilateral berbasis role playing game.

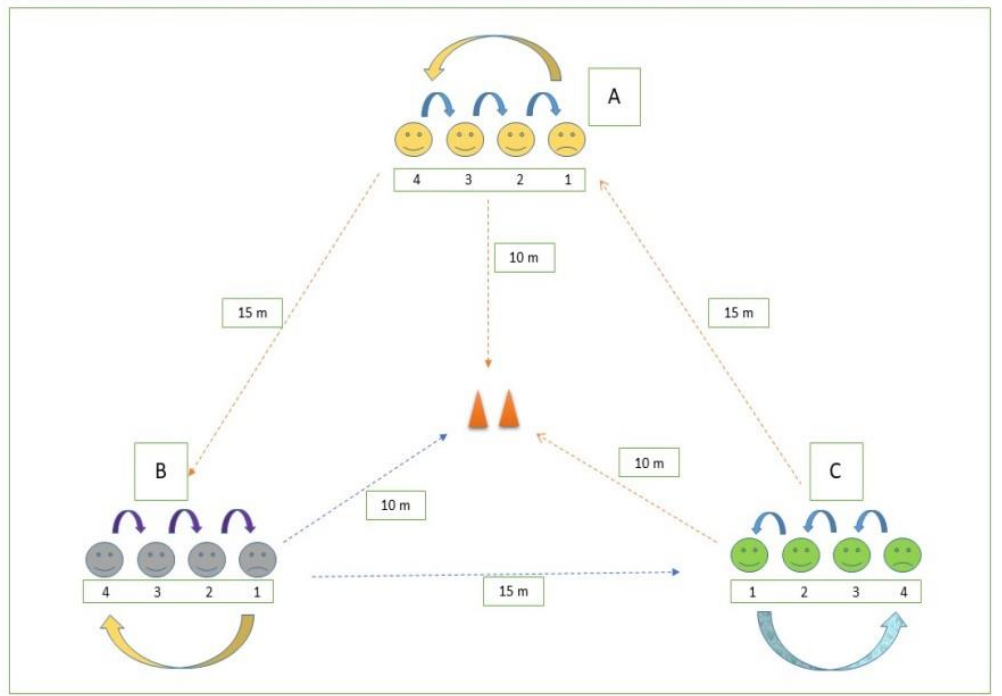

Gambar 1. Model akhir gerak multilateral berbasis role playing game

Berdasarkan gambar diatas maka dapat dijelaskan cara bermain sebagai berikut:

1. Permainan dimulai setelah mendengar aba-aba/peluit dari guru.

2. Setiap regu melakukan gerakan:

a. Siswa pertama masing-masing regu melakukan gerakan memantulkan bola.

b. Regu kedua melakukan gerakan melambungkan bola.

c. Regu ketiga melakukan gerakan menggelindingkan bola

d. Regu Keempat melakukan gerakan melompat.

e. Setelah ada aba-aba atau peluit maka siswa di barisan pertama dalam setiap regu melakukan lari sprint menuju ke arah cone yang sudah ditentukan.

f. Siswa yang terakhir menuju kearah cone maka akan mendapat hukuman yang telah disepakati bersama dari masing-masing regu.

g. Permainan akan dimulai lagi dengan bertukar posisi dalam setiap regu.

h. Setelah semua siswa dalam satu regu sudah melakukan maka posisi regu bergantian.

\section{PEMBAHASAN}

Pengembangan model pembelajaran gerak multilateral berbasis role playing game ini dilakukan dengan melalui berbagai tahapan diantaranya: 1) Melakukan analisis kebutuhan terlebih dahulu pada guru pendidikan jasmani dan siswa, 2) Membuat rancangan produk awal atau model gerak multilateral berbasis role playing game, 3) Evaluasi ahli terhadap model yang sudah dibuat dengan melibatkan 2 ahli pembelajaran dan 1 ahli pendidikan jasmani, 4) Melaksanakan ujicoba kelompok kecil dengan melibatkan 10 subjek siswa kelas bawah, 5) Revisi produk dari hasil ujicoba kelompok kecil, 6) Melakukan ujicoba kelompok besar dengan melibatkan 35 subjek, 7) Menyempurnakan produk berdasarkan hasil ujicoba kelompok besar. Berdasarkan dari data hasil ujicoba kelompok kecil dan ujicoba kelompok besar yang dilakukan oleh siswa kelas bawah pada SD Muhammadiyah Pangkalpinang, maka ada beberapa bagian pada model gerak multilateral berbasis role playing game yang perlu diperbaiki. Hal ini dilakukan untuk mengoptimalkan manfaat pengembangan model gerak multilateral berbasis role playing game bagi siswa kelas bawah.

Adapun beberapa saran maupun perbaikan serta kesimpulan dari ketiga ahli bahwa produk gerak multilateral berbasis role playing game yang dikembangkan secara keseluruhan memenuhi standar serta layak untuk digunakan. Namun untuk lebih menyempurnakan model tersebut ada beberapa saran diantaranya: 1) aktivitas gerak harus disesuaikan dengan karakteristik pertumbuhan dan perkembangan siswa, dalam hal ini khususnya siswa sekolah dasar kelas bawah, 2) pelaksanaan model harus tergambar dengan jelas, berikut dengan aturan mainnya, 3) untuk ukuran lapangan serta jarak dari masing-masing pemain harus jelas. Pada tahap revisi yang kedua dilakukan setelah ujicoba kelompok kecil. Adapun catatan lapangan serta saran sebagai

\section{Dipublikasikan Oleh :}


berikut: 1) Disesuaikan lamanya waktu untuk melakukan model tersebut, sehingga siswa yang mempraktikkan tidak merasa bosan, 2) mencantumkan tujuan model atau produk yang telah dibuat. Tahap revisi ketiga dilaksanakan setelah melakukan ujicoba kelompok besar. Setelah dilakukan ujicoba ternyata model gerak multilateral berbasis role playing game tidak ada yang perlu diperbaiki atau direvisi, sehingga semua aspek sudah dinyatakan sangat layak untuk di terapkan pada siswa sekolah dasar kelas bawah.

Melihat hasil penelitian yang sudah dilakukan bahwa model aktivitas gerak multilateral berbasis role plaing game dinyatakan layak maka sudah saatnya bagi guru pendidikan jasmani olahraga dan kesehatan tingkat sekolah dasar mampu untuk memanfaatkan model pembelajaran yang inovatif. Suasana pembelajaran yang efektif sudah seharusnya siswa dilibatkan secara aktif karena siswa menjadi pusat dari proses belajar mengajar. Model pembelajaran sangat erat kaitannya dengan gaya mengajar seorang guru dan gaya belajar siswa. Upaya guru dalam mengajar siswa merupakan bagian yang sangat penting untuk mencapai keberhasilan siswa sesuai dengan tujuan pembelajaran yang sudah direncanakan. Oleh karena itu pemilihan strategi, metode, dan menentukan model pembelajaran yang tepat merupakan suatu hal yang utama bagi guru dalam proses pembelajaran.

\section{PENUTUP \\ KESIMPULAN}

Hasil akhir dari penelitian pengembangan ini yaitu produk model gerak multilateral berbasis role playing game yang sudah divalidasi oleh 3 orang ahli dan sudah di lakukan ujicoba kelompok kecil dengan jumlah subjek 10 siswa dan ujicoba kelompok besar dengan jumlah subjek 35 siswa. Hasil ketiga evaluasi ahli diperoleh nilai rata-rata sebesar $93,1 \%$ yang berarti bahwa model gerak multilateral berbasis role playing game sangat layak untuk diterapkan, sehingga atas dasar hasil tersebut bahwa produk tersebut siap untuk diujicobakan dalam kelompok kecil. Dari hasil ujicoba kelompok kecil yang melibatkan aspek kognitif, afektif dan psikomotorik diperoleh nilai rata-rata sebesar $87,5 \%$ dan berada pada kriteria sangat layak. Hasil ujicoba kelompok besar yang melibatkan aspek kognitif, afektif, dan psikomotorik diperoleh nilai rata-rata sebesar $88,8 \%$ dan berada pada kategori sangat layak. Maka secara keseluruhan bahwa model gerak multilateral berbasis role playing game sangat layak untuk diterapkan dan digunakan pada siswa Sekolah Dasar Muhammadiyah kelas bawah Pangkalpinang. Pengembangan gerak multilateral berbasis role playing game ini mengajarkan siswa untuk melakukan gerak dasar seperti memantulkan bola, menggelindingkan bola, gerakan membungkuk, dan gerakan melompat yang dikombinasikan melalui permainan. Gerak dasar tersebut sangat penting untuk diajarkan kepada siswa karena sebagai dasar untuk mengembangkan kemampuan geraknya. Pembelajaran Gerak Dasar melalui permainan dapat meningkatkan kemampuan kognitif, apektif, dan psikomotor. karena dalam permainan siswa dapat belajar secara langsung dengan praktik langsung gerak dasar dalam permainan serta mengenal sikap-sikap dalam permainan,

\section{REFERENSI}

Ahmad Rithaudin. (2011). Survei Model Aktivitas Pengembangan Keterampilan Gerak Dasar di Sekolah Dasar Se-Kecamatan Pengasih Kulon Progo.Jurnal Pendidikan Jasmani Indonesia, 8(1), 31-37.

Badan Standar Nasional Pendidikan (BSNP) Depdiknas. (2005). Pembelajaran Pendidikan Jasmani. Jakarta: Depdiknas.

Bakhtiar, S. (1999). Kemampuan Gerak Dasar Pelajar Se-kolah Dasar Negeri Kota Padang. Laporan Pene-litian tidak diterbitkan. Padang: IKIP Padang.

Cerika Rismayanthi. (2013). Mengembangkan Keterampilan Gerak Dasar Sebagai Stimulasi Motorik Bagi Anak Taman Kanak-Kanak Melalui Aktivitas Jasmani. Jurnal Pendidikan Jasmani Indonesia. 9(1), 69.

Gallahue, D.L., Ozmun, J.C., \& Goodway, J.D. 2012. Un-derstanding Motor Development: Infants, Children, Adolescent and Adults (7th ed). Boston: McGraw-Hill.

Goodway, J. D., Ozmun, J. C., \& Gallahue, D. L. (2019). Understanding motor development: Infants, children, adolescents, adults. Jones \& Bartlett Learning.

Hanief, Y. N. \& Sugito. (2015). Membentuk Gerak Dasar Pada Siswa Sekolah Dasar Melalui Permainan Tradisional. Jurnal SPORTIF : Jurnal Penelitian pembelajaran, 1(1), 60-73.

Hopkins, D. (2008). A teacher's guide to classroom research. New York: Open University Press.

Husdarta, J.S. (2011). Manajemen Pendidikan Jasmani. Bandung: Alfabeta.

Pangrazi, Robert. (2007). Dynamic Physical Education for Elementary School Children (15th ed.). San Francisco: Pearson Benjamin Cummings. 
Rahyubi, H. (2012). Teori-teori Belajar dan Aplikasi Pembelajaran Motorik. Majalengka: Referens.

Ria Lumintuarso. (2013). Pembinaan Multilateral Bagi atlet Pemula. Yogyakarta: UNY Press.

Sari Kurnia Wening, Sulistyo Saputro, Budi Hastuti. (2014). Pengembangan Game Edukasi Kimia Berbasis Role Playing Game pada Materi Struktur Atom sebagai Media Pembelajaran Mandiri Untuk Siswa Kelas X SMA Di Kabupaten Purworejo. Jurnal Pendidikan Kimia, 3(2), 96-104.

Sudjana. (2005). Metode Statistika. Bandung: Tarsito.

Suparno. (2013). Dampak Permainan Bowling Tiruan terha-dap Kecakapan Motorik Anak Terbelakang Mental Usia Dini. Jurnal Ilmu Pendidikan, 19 (2): 155-160.

Syahrial Bakhitar, (2014). Strategi Pembelajaran, Lokasi Sekolah, dan Kemampuan Gerak Dasar Siswa Sekolah Dasar. Jurnal Ilmu Pendidikan, 20 (2):127-133.

Prayitno \& Sukadiyanto. (2014). Pengembangan Model Pembelajaran Gerak Dasar untuk Anak Usia 2-4 Tahun. Yogjakarta: Jurnal Keolahragaan UNY 2(1), 11-21. https://doi.org/10.21831/jk.v2i1.2566

Waluyo, T. (2018, December 4). The Development of Multilateral Movement Skill Teaching Models Based Games for The 2nd Grade Student of Elementary School. https://doi.org/10.31219/osf.io/jhg5t 